特集 2 家族のライフスタイル

\title{
ポストモダンの家族ライフスタイル テーマ設定の意義
}

野々山 久 也

1.はじめに

かつて産業化や都市化を背景にしてムラという伝統的な地域共同社会が崩壊していくにつれて、わが 国における家族ならびに親族の社会的構造に大きな変化が生じた。それは、イエとよばれた直系制家族 やそのイエとイエの連合体であった同族集団の解体化であり、一般的には、いわゆる「核家族化」とよ ばれるようになった家族変動であった。

核家族化とは、それまで伝統的に家族が果たすものとされてきた多くの機能がその他の専門機関に肩 代わりされるようになってきて、核家族という家族形態が家族の典型とみなされるようになり、性別役 割分業をはじめ、その生活様式や規範や下位文化が標準的な家族として培われるようになってきたプロ セスをいう。ときに、この標準的な家族は「近代的家族」とよばれたりするようになった。

わが国においては、1920年ごろを境にして、それまでほほ安定していた平均出生児数が減少しはじめ る。国家によるイデオロギー的操作を別にすれば、現実としての核家族化は、その意味ではすでにこの 時期に開始しはじめていた。イデオロギーとしての核家族化あるいは家族の近代化は、第二次世界大戦 後になって開始したといってよいが、現実としての核家族化の開始という点からすれば、わが国におけ る近代的家族の端初は、すでにこの時期から開始しはじめたということができる。

以上のことを前提にして、わが国における家族の近代化、すなわち近代的家族の台頭は、次のような プロセスをとおして開始しはじめた。すなわち、それまでイエやムラが主体となって、そこでの食いぶ ちと働き手との関数から堕胎や間引きなどによる人為的な抑制をとおして、それなりに子どもの適正人 数が割出されていたが、のちに避妊の知識や技術の普及をとおして、伝統的な地域共同社会の解体の始 まりとともに個々の家族が個別的に産む産まないを判断し、調節しはじめるようになり、いわゆる家族 の私事化への端初が開始しはじめた。

しかし私事化への志向が開始しはじめたからといって、この段階での核家族化は、規範や生活様式と しての固定的な性別役割分業のもとにただちに少子化をもたらすようなことはなかった。おりから産業 化の進展は、農村から都市へと労働力の吸収をとおしてイエやムラの解体化を促すようになった。少子 化にまで至らない核家族化は、産業化にとって順機能的であったがゆえに、高度産業化を促進しょうと する国家によって目標推進のためのイデオロギーとしても採用された。かくして、わが国における高度 経済成長は、核家族化を背景にして達成することができた。 
さて、ここまで論じてきて、つぎに家族社会学者たちに問われることは、「いま家族に生じている諸現 象（多様化、私事化、少子化、非婚化、夫婦別姓化など)」をこのように過去の経過から解説するだけで は現象の半分しか説明できないのではないかということである。今回の第25回家族社会学セミナー（第 2 回日本家族社会学会大会) において筆者らがテーマ・セッションを呼びかけ、表題のようなテーマを 設定することになったのは、家族社会学者たちへの、まさにこのような問いかけにたいする回答を多く の参加者を得て、互いに持ち合わせているデータをもとにして論じ合いたいと考えたからであった。

表題から判断できるように、筆者の立場は、今日の家族にかかわる諸現象は過去というょりは将来、 すなわち近代（モダン）というよりは、脱近代（ポストモダン）との関わりにおいて論じられなければ、 その回答は得られないだろうという考え方に立っている。

\section{2. ポストモダンについて}

周知のとおり、今回の家族社会学セミナーのテーマ・セッションにおけるタイトルは、「ポストモダン の家族ライフスタイルについて」であった。このテーマそのものについてフロアからいくつかの疑問が 提出された。それらを要約すれば、ほほ次の二つであった。一つは、「ポストモダンについて」であり、 もう一つは、「家族ライフスタイルについて」であった。当日は時間的な制約もあって十分な回答を示す ことができなかった。そこで、ここでこの二つの疑問にたいして何らかの回答を提示しておきたい。

まずポストモダンについてであるが、いうまでもなく今回のテーマ・セッションではポストモダンそ れ自体を論じょうなどという問題提起がなされたわけでは決してない。その意味では、ここで問題にさ れなければならないのはポストモダンそのものではなく、「ポストモダン家族」すなわち「脱近代家族」 についてである。したがって、近代的家族にたいして脱近代的家族とは何かについて、換言すれば、家 族の脱近代化論について論じ合うことこそが、じつはテーマ・セッションの大きな狙いであったという ことになる。

これまで、わが国における家族社会学者たちは、どちらかというと家族の将来について予測すること を避けてきた。端的な言いかたをすれば、それは現代家族を理解するのにもっぱら過去から現在にいた る過程、すなわち「家族の近代化」を分析することで精いっぱいであった。それだけの余裕がなかった というのが正しいかもしれない。

しかしながら、核家族化の進展がもはや核家族化の終焉に近づきつつある今日、新しい家族の動向を 読みとることは家族社会学者たちに期待された重要な課題である。危機に立つ家族であるとか摇れ動く 家族などと傍観者的な立場にたって現状を危機煽動的に記述しているだけでなく、ことの本質を現代家 族が展開しつつある将来への動向との関連で明らかにすることは、いずれにしろ今日の家族社会学者た ちに課せられた課題である。今回のテーマ設定にあたって筆者が考えたことは、いま「家族の脱近代化」 について論じ合うことがその今日的課題に答える焦点ではないのかということであった。

ところで、これまで「なぜ家族がある行動を行なうのか」について説明するのに、主として社会的規 範という変数によって説明されてきた。そして「なぜある家族がある行動を行なうのに、べつの家族が べつの行動を行なうのか」については、主としてそれぞれの家族の集団メカニズムという変数によって 
説明されてきた。すなわち、これまでの家族社会学研究においては前近代的家族ならびに近代的家族に ついて一定の規範を確認することができていた。そして、それなりにモーダル・パターンとしての家族 集団のライフサイクルを確認することができていた。

しかしながら今日、産業化の進展の結果、高度情報社会や高度技術社会の展開によって従来からの規 範の拘束力を無効にするような諸現象が家族や家族関係に押しよせてきた。労働の中核が肉体労働から 知的労働へと変化するにつれて高等教育の一般化とともに「高学歴化」が進展し、労働力における性差 の縮少が生じたり、女性の家庭外就労が増大したりしてきた。また合理主義的な精神の浸透によって因 習的宗教の影響力も低下してきた。

一方、人口の都市への集中を中心にした都市化の進展は、多種多様な人びとの都市への流入とともに 都市の肥大化をもたらし、大都市への極端な人口の集中と極端な流動化を生じさせてきた。こうした「超 都市化」は、都市人口が互いに匿名的であることを背景にして多価值化ならびに多様な下位文化を培い つつある。そして、その匿名性の増幅は、当然のこととして従来からの家族や家族関係に関しての規範 の拘束力を無効にする結果を生じさせている。

また夫婦のそれぞれの平均寿命の伸長にともなって、従来からの伝統的な家族周期パターンの変化な らびにその伝統的パターンによる拘束力の無効化が生じてきている。そして、さらに社会全体ならびに その下位システムにおける構造機能的な分化と細分化にともなって、家族成員のそれぞれにおける社会 的ネットワークの個別化とその異質性の拡大が生じ、家族が一つの集団として統合性を維持しにくい状 況が生じてきている。

したがって現代家族は、家族や家族関係にかかわる前近代的ならびに近代的な規範や価値による拘束 性からじょじょに解放されはじめ、さまざまな規範や価值を自主的に選択しなければならない状況に置 かれだしている。あるいは現実的には自主的な選択というよりは極めて状況規定的な選択しかできない 状態に置かれている。それはときに「家族する」家族とか、あるいは「家族しない」家族に見えたりも する。

いずれにしろ、わが国における家族の脱近代化は、いま大きなうねりをもって開始しはじめた。それ は、人間性の尊重や個性の解放をめざしているという点をのぞいて、決して古典的文化あるいは伝統的 文化の復興という意味での家族のルネッサンスなどではありえない。

\section{3. 家族ライフスタイルについて}

規範の解体は、確かに一時的にはアノミー状況をつくりだす。そのことをもって現代家族の危機ある いは病理として静態的に理解するアプローチもそれなりに成立するかもしれない。しかし動態的アプ ローチからすれば、今日の諸現象は、家族の脱近代化の過程における新しい秩序の模索と形成のプロセ スということになる。その場合、問題となることは、どのような秩序が形成されることになるのかとい うことである。

「家族ライフスタイル」という概念は、その新しい秩序を理解するためのキー・タームとして提案しよ うとしている。そこで、つぎに家族生活様式とせずに、なぜ家族ライフスタイルとカタカナにしている 
のかについて、いくらかの回答を試みておきたい。

すでに述べたように産業化や都市化を背景にして、わが国の家族の近代化も進展してきたが、とくに 第二次世界大戦後は、憲法や民法の改正によって民主主義思想や人権思想の樹立のための基礎が確立し た。そして民主主義思想や人権思想は、個人の基本的人権、自由、平等、参加、独立、自尊などといっ た個人主義思想の展開を促した。もちろん、それは利己主義や自己中心主義なども随伴したが、とにか く個人優先主義をおおいに育む結果となった。

家族生活様式といえば、家族生活にかかわる既存の制度や規範にもとづいて形成された家族形態や家 族構造など一般を意味し、一般的にそのモーダル・パターンを予測できるような家族文化にほかならな い。家族生活様式は、その意味では家族生活を社会という視点から捉えようとする用語である。一方、

家族ライフスタイルをここで定義づけておくとすれば、「家族生活にかかわる生活諸関係ならびに生活諸 資源にたいする個人の自主的な選択行動のパターン」ということになる。その意味では家族ライフスタ イルは、家族生活を個人という視点から捉えようとする用語である。

しかし重要な点は、社会か個人かという視点の違いだけではない。それはむしろ本人にとってそれが 拘束的か、あるいは自主的な選択によるものかという違いである。家族ライフスタイルは、すでに述べ たように家族や家族関係にかかわる従来からの規範の拘束力が弱化するにつれて従来からの規範とはべ つに個人が自主的に選択するようになる行動パターンである。たとえば、結婚適齢期などといった従来 からの規範ないしはモーダル・パターンに拘束されることなく、「本人が結婚したくなったときが適齢 期」というように個人の自主的な選択を重視したときに要請される概念である。

これまで家族社会学では社会という視点が重視されて、「制度としての家族」あるいは「集団としての 家族」という側面が強調されてきたが、家族ライフスタイルという概念の登場とともに、個人という視 点が重視されて「ライフスタイルとしての家族」という側面が強調されることになる。カタカナでなく てはならない理由は、まさにそれが個人のライフスタイルそのものにほかならないからである。

家族をめぐる今日の諸現象、たとえば、晚婚化や晚産化をはじめ、家族の多様化、私事化、少子化、 個別化、DINKS、非婚化、個人志向化など、すべて家族ライフスタイルという概念を無視して理解する ことは困難である。というよりは、これらの諸現象は、家族ライフスタイルという概念の採用によって 最もよく理解することができる。そして、おそらく家族ライフスタイルに代わる有効な概念を見出すこ とは、しばらくは難しいことではないだろうか。

\section{4.おわりに}

第25回セミナーでは、周知のとおり、(1)神原文子「家族ライフスタイルの多様化を考える」、(2)善積京 子「非婚家族のライフスタイルについて」、そして(3)渡辺秀樹「家族ライフイベントのゆくえ」という三 名の有力な参加協力者ならびにその報告を得ることができた。ここで三名の報告者の労にたいして敬意 を表すとともに、心から御礼を申し上げたい。

報告内容の詳細については、本誌のこのあとのそれぞれの論考を参照されたいが、セミナー当日は、 ほほ次のような要旨の報告であった。まず神原は、家族ライフスタイルの多様化の背景について論じ、 
その促進要因と阻止要因についての検討を試みる報告を行なった。多様化の方向としては、まず個人に おける家族とのかかわり方の多様化、つぎに家族システムにおける家族ライフスタイルの多様化、そし て家族制度の修正・再編にもとづく「家族」ライフスタイルの多様化などが考えられると論じた。

つぎに善積は、主として西欧諸国での非婚化の動向についてその実態と社会的背景について検討し、 わが国における今後の可能性を探ろうとする報告を行なった。西欧でも非婚の男女共同生活は、スウェー デンをのぞいて、まだ法的レベルでは完全には受け入れられていないが、その増加によって危惧される ような社会的混乱や性的無秩序が起きなかったことから、熟慮の末に選ばれた事実上の結合とみなされ、 社会的に許容されてきていると報告した。

そして渡辺は、ポストモダンの家族ライフスタイルについて追究するさいの一つの方法として、個人 による家族ライフイベント（たとえば結婚、離婚、出産など）の経験の仕かたという点から、家族ライ フイベントについての経験の前後の生活の変化あるいは異なる家族ライフイベントを経験することによ る生活の違いなどに注目する方法があることを報告した。そのうえでイベント経験の前後での生活の違 いが小さいとき、家族のオールタナティヴ・ライフスタイルは成立可能となるが、逆に、違いが大きい とき、それは成立しにくいと論じ、成立可能性についての諸要因ならびにそのメカニズムについて報告 した。

ポストモダンの家族ライフスタイルについての研究は、いま緒についたばかりである。これを機会に して今後、家族社会学研究においてこの領域に関しての研究や議論がおおいに発展することを切に期待 したい。

（ののやま ひさや・甲南大学） 


\section{Recent Experiences of Scientific Exchange with Chinese Scholars : An Appraisal}

Kiyomi Morioka

The present paper reports about the two successive Japan-China conferences held recently in Beijing (1991) and Hangzhou (1992) under the sponsorship of the Japan Society for Promotion of Science, with the purpose of exchanging major research ideas, methods and findings in current family studies as well as promoting bi-lateral collaboration in the near future. The Japanese participants learned a great deal about the reality of the Chinese family and household through the conferences, and also from on-the-spot observations which follwed the intensive sessions of reports and discussions. At the same time, we felt frustrated by the ambiguity of the definition of key terms such as 家, 家庭, and 戸, used in Chinese reports. This paper examines some of these issues. Wider exchange and closer collaboration with Chinese scholars in the future will certainly improve and enrich our understanding of the marriage and family phenomena in China.

\section{Family Lifestyles in Post-modern Society \\ The Significance of This Theme -}

Hisaya Nonoyama

At the 25th seminar of family sociology last year, family lifestyles in post-modern society was proposed as a theme for one of the sessions. Of the questions asked from the floor, one concerned the term "post-modern society" and another the term "family lifestyles."

Rather than discuss post-modern society itself, the intention was to discuss the nature of the post modern family. A new concept of "Family Lifestyle" is required in order to discuss the post modern family, because it is useful, even crucial, for understanding post modern families in that it allows us to treat the family as a lifestyle which is individually chosen.

Fortunately, three valuable reports were presented at that seminar on this theme, and are included in this joural on the following pages.

\section{Significance of Lifestyle Analysis in Family Studeis}

Fumiko Kanbara

Lifestyle analysis is a theoretical and methodological approach for examining individual approaches to assembling one's own life, which uses as its unit of analyzing individual living persons (or living entites) who are "leading their daily lives while building up a life aimed at creating a personalized life based on their own individual interests as living entities".

The objectives of introducing the lifestyle concept into family study include the following.

1. To clarify the significance of the existence of the family for individuals. That is, to elucidate the lifestyle 